\section{Pacific Northwest}

National Laboratory

Operated by Battelle for the

U.S. Department of Energy

\title{
Site Characterization Plan: \\ Uranium Stabilization through Polyphosphate Injection
}

\author{
V. R. Vermeul \\ J. S. Fruchter \\ D. M. Wellman \\ B. A. Williams \\ M.D. Williams
}

August 2006

Prepared for the U.S. Department of Energy under Contract DE-AC05-76RL01830 


\section{Site Characterization Plan: \\ Uranium Stabilization through Polyphosphate Injection}

300 Area Uranium Plume Treatability

Demonstration Project

V. R. Vermeul

J. S. Fruchter

D. M. Wellman

B. A. Williams

M.D. Williams

August 2006

Prepared for

the U.S. Department of Energy

under Contract DE-AC05-76RL01830

Pacific Northwest National Laboratory

Richland, Washington 99352 


\section{Summary}

An initial feasibility study of options to treat the uranium plume at the 300-FF-5 Operable Unit considered hydraulic containment, slurry wall containment, and groundwater extraction as potential remedial action technologies. None were selected for interim action, and reduction of contamination levels by natural processes was considered a viable alternative while source removal actions continued. Subsequent planning for a Phase III feasibility study focused on methods that would reduce the concentration of uranium in the aquifer, including multiple methods to immobilize uranium using chemical-based technologies. Based on an initial technology screening, the polyphosphate technology was identified as the best candidate for further evaluation and selected for treatability testing.

The overall objective of the polyphosphate treatability test is to evaluate the efficacy of using polyphosphate injections to treat uranium contaminated groundwater in situ. The objective of the work elements included in this site characterization plan is to collect site-specific characterization data that will be needed to design and implement a field-scale demonstration of the technology. 



\section{Contents}

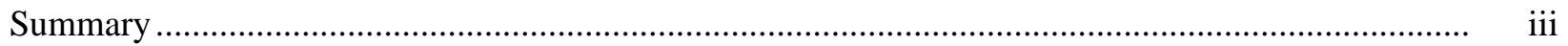

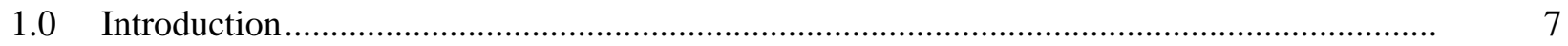

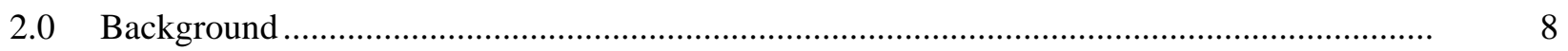

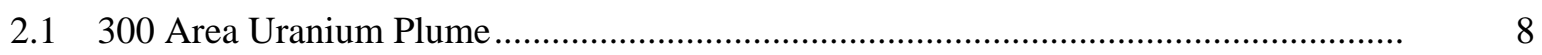

2.2 300-FF-5 Limited Field Investigation ......................................................................... 9

2.3 Public Involvement in 300 Area Groundwater Decisions ............................................ 11

2.4 Polyphosphate Technology Description.................................................................. 11

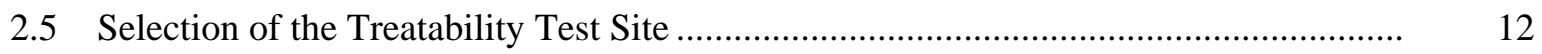

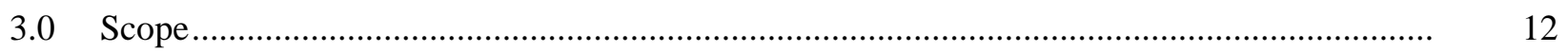

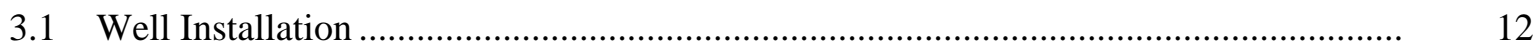

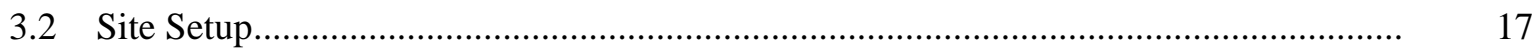

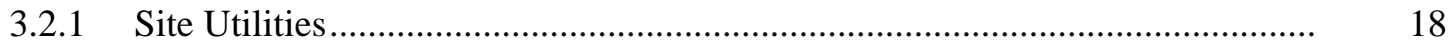

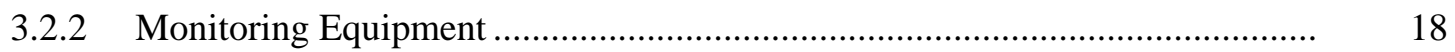

3.2.3 Injection and Withdrawal Equipment............................................................. 19

3.2.4 Description of Equipment Integration/Operation ............................................ 20

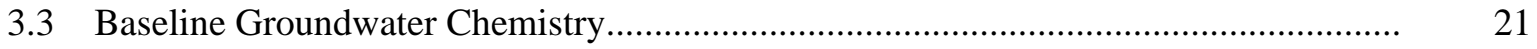

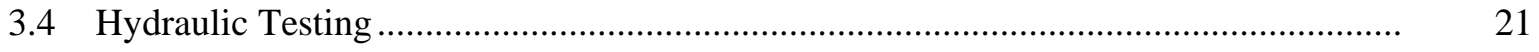

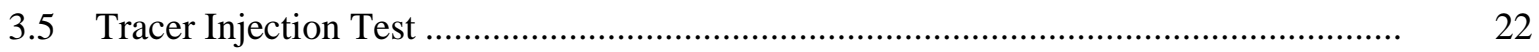

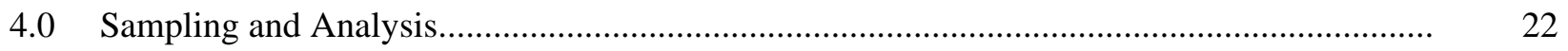

5.0 Data Recording/Management/Reporting ...................................................................... 24

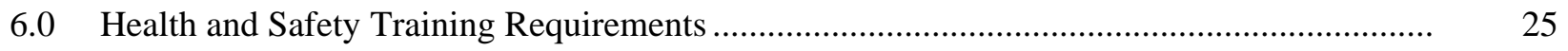

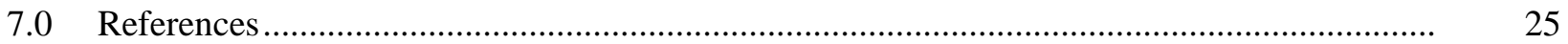

\section{Figures}

1. LFI Characterization Well Location Map ................................................................................. 10

2. Polyphosphate Treatability Test Site Location, 300-FF-5 Operable Unit, 300 Area................... 13

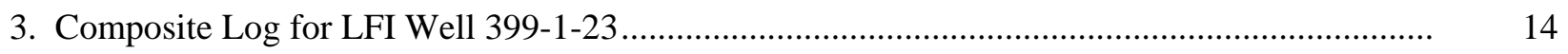

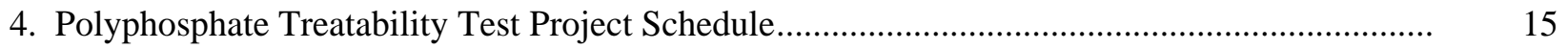

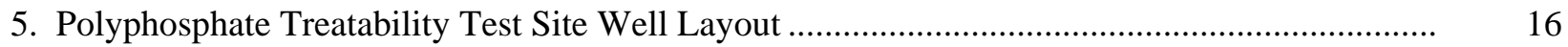




\section{Tables}

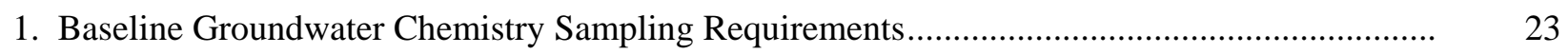

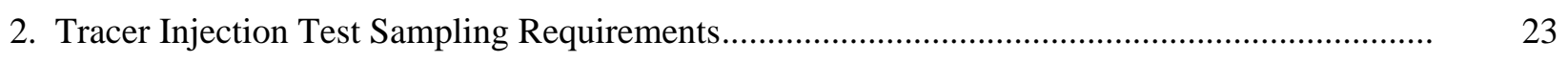

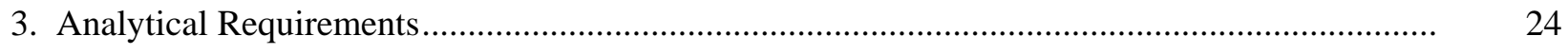




\subsection{Introduction}

This site characterization plan covers work elements associated with site-specific characterization of the polyphosphate treatability test site. Polyphosphate treatment shows promise for reducing the concentration of dissolved uranium in a plume that has persisted beneath the 300 Area for some time. The polyphosphate technology was selected for further testing during the 300-FF-5 Phase III Feasibility Study technology screening process. An initial feasibility study (DOE 1995) for the 300-FF-5 uranium plume considered hydraulic containment, slurry wall containment, and groundwater extraction as potential remedial action technologies. None were selected for interim action, and reduction of contamination levels by natural processes was considered a viable alternative while source removal actions continued.

Subsequent planning for a Phase III feasibility study focused on methods that would reduce the concentration of uranium in the aquifer, including multiple methods to immobilize uranium using chemical-based technologies. Based on this initial technology screening, the polyphosphate technology was identified as the best candidate for further evaluation and selected for treatability testing. The objective of the polyphosphate treatability test is to evaluate the efficacy of using polyphosphate injections to reduce uranium concentrations in groundwater to meet drinking water standards (30 ug/L) in situ. The work elements described in this site characterization plan pertain to the collection of sitespecific characterization data that will be needed to design and implement a field-scale demonstration of the technology.

Data collected during the 300-FF-5 Limited Field Investigation (LFI) are being used to refine the hydrogeologic and geochemical conceptual model for the uranium plume that is the target of this treatability test. Information developed under several research investigations into the geochemistry of uranium in the 300 Area (Serne et al. 2002; Zachara et al. 2005) has also contributed significantly to refining the conceptual site model for uranium contamination. These results have been used to select an appropriate site for a field-scale demonstration of the polyphosphate treatment technology. Well 399-123, which was installed as part of the LFI, has been identified as the preferred location for a field-scale demonstration of the technology. The remaining sections of this plan are written based on this assumption; if an alternate site is selected due to logistical or regulatory concerns, a characterization plan addendum will be issued documenting any variances. During this characterization effort, monitoring wells will be installed in the vicinity of the selected injection well. It is anticipated that up to six monitoring wells will be installed within the radial extent of the initial treatment zone, and an additional two to three monitoring wells will be installed to monitor downgradient transport of the polyphosphate amendment.

Following installation of the monitoring well network, several hydrogeologic characterization methods will be used to obtain additional site-specific information. Planned activities include (1) site setup, (2) collection of baseline groundwater chemistry samples, (3) hydraulic testing to obtain formation hydraulic properties, (4) electromagnetic borehole flowmeter (EBF) testing to assess the vertical distribution of horizontal hydraulic conductivity (i.e., vertical heterogeneities), and (5) a conservative tracer injection test. The tracer test will be used to further evaluate formation heterogeneities, to assess the downgradient transport of the tracer plume (i.e., aquifer transport properties), to refine the polyphosphate injection design, and to test operational procedures. 


\subsection{Background}

This section provides background information on the 300 Area uranium plume and the evolution of activities that will ultimately lead to a remedial action decision. In 1996, a record of decision (EPA 1996) identified the following interim actions for remediation of the uranium contaminant plume beneath the site:

- Continued groundwater monitoring to determine how contaminant conditions may change with time.

- Institutional controls to limit the use of groundwater.

The interim action results have determined that uranium concentrations in the groundwater plume have been generally declining, but still persist at concentrations above the drinking water standard (remediation goal). Therefore, re-evaluation of the remedy for uranium contamination is necessary because the rate of decrease in uranium concentrations is significantly different than the rate of decrease expected and used as a basis for the remedy selection in the current record of decision.

\subsection{Area Uranium Plume}

A groundwater plume containing uranium from past-practice discharges of liquid waste associated with nuclear fuel fabrication activities has persisted beneath the Hanford Site 300 Area for many years. The persistence of this plume is enigmatic for several reasons, including (1) discharges containing uranium-bearing effluent to ground disposal sites ended in the mid-1980s; (2) contaminated soil associated with these waste sites was removed during the 1990s, with backfilling complete by early 2004; and (3) the aquifer is comprised of highly transmissive fluvial sediment, suggesting rapid movement of groundwater. Also, a water supply well located within the plume has been in operation since 1980, with no observable effect on the plume. The current conceptual site model assumes that re-supply of the plume is occurring, with continuing release from the vadose zone beneath waste sites, the capillary fringe zone, and possibly from aquifer solids, as source candidates (Peterson et al. 2005).

A remedial investigation conducted in the early 1990s, along with an expedited response action to remove contaminated soil from the most recently used disposal site, led to a 1996 record of decision (EPA 1996) for interim remedial action that involved continued groundwater monitoring and institution controls on the use of groundwater. Characterization of natural features and processes that would lead to attenuation of the contamination is part of the interim action, which continues. A computer simulation of the plume during the initial remedial investigation led to a prediction that concentrations would decrease to the proposed drinking water standard (20 $\mathrm{g} / \mathrm{L}$ in 1993) in 3 to 10 years from 1993, assuming no re-supply of uranium to the plume (DOE 1995). This predicted response has not been observed in monitoring well trend data.

Maximum concentrations in the plume are currently less than $250 \mu \mathrm{g} / \mathrm{L}$, with mode values ranging from 30 to $90 \mu \mathrm{g} / \mathrm{L}$. The plume ( $>30 \mu \mathrm{g} / \mathrm{L}$ ) currently covers an area of $\sim 0.4 \mathrm{~km}^{2}\left(0.15 \mathrm{mi}^{2}\right)$. Assuming a representative thickness of the contaminated layer of $3.3 \mathrm{~m}(10.8 \mathrm{ft})$ and $27 \%$ porosity, the volume of contaminated groundwater is $\sim 350,000 \mathrm{~m}^{3}\left(460,000 \mathrm{yd}^{3}\right)$ and the mass of dissolved uranium is $\sim 20 \mathrm{~kg}$ (Peterson et al. 2005). The length of Columbia River shoreline impacted is $\sim 1,500 \mathrm{~m}(4,900 \mathrm{ft})$. Uranium removal via a water supply well for the 331 Life Sciences Building is $\sim 21 \mathrm{~kg} / \mathrm{yr}$, based on monitoring 
data. Detailed estimates for the net flux of uranium to the river are not yet available, but are expected soon as a product of computer simulation efforts. Note: Although groundwater flow rates are high, net discharge to the Columbia River is tempered by bank storage effects created by river stage fluctuations (Waichler and Yabusaki 2005).

Principal investigations leading to the current conceptual site model for this plume include early work to describe the hydrogeology and groundwater contamination of the 300 Area (Lindberg and Bond 1979); detailed investigations to support RCRA requirements at the 300 Area Process Trenches (Schalla et al. 1988); and the initial remedial investigation under CERCLA for the 300-FF-5 groundwater operable unit (DOE 1995). More recently, detailed geochemical research involving uranium in 300 Area sediment has been conducted to support decisions associated with cleanup of surface waste sites (Serne et al. 2002) and the renewed feasibility study of potential remedial action alternatives for the plume (Zachara et al. 2005). The latter investigations, which were conducted under the DOE's science and technology research programs, included sampling the vadose zone beneath two major liquid waste disposal sites located near the proposed treatability test site (well 399-1-23). Samples from vertical profiles that spanned the base of the disposal site excavations down to the water table were collected, and subjected to intensive laboratory investigations to determine the geochemical and mobility characteristics of residual uranium in the lower vadose zone.

\section{$2.2 \quad 300-F F-5$ Limited Field Investigation}

An LFI is being conducted as part of the Phase III Feasibility Study to reduce uncertainties in two aspects of the conceptual model for the uranium plume: (1) the vertical distribution of uranium in the vadose zone and uppermost aquifer at representative sites, with special emphasis on the interface between unsaturated and saturated conditions (i.e., the capillary fringe zone) and geochemical characteristics that influence the mobility of uranium, and (2) the vertical and lateral distribution of uranium throughout the mapped plume area where drinking water standards are exceeded (DOE 2006).

The first phase of the LFI characterization is complete. This included collecting continuous core samples and depth-discrete groundwater samples, and conducting aquifer tests from four sites that are representative of various combinations of proximity to waste sites and to the river, and in various hydrogeologic environments (Figure 1). The entire LFI area of interest is defined by the extent of the uranium plume, i.e., the area where concentrations are above natural background levels (i.e., above $\sim 10 \mu \mathrm{g} / \mathrm{L}$ ). The extent and general shape of this area has not changed appreciably for many years (Peterson et al. 2005). The distribution pattern of the higher concentrations within this area varies significantly with time and is thought to be a consequence of liquid effluent disposal activities, source excavation activities, fluctuations in water-table elevations, and plume migration. Results from drilling and characterization in the four new wells indicate that the highest groundwater and vadose concentration of uranium is in the two downgradient wells 399-1-23 (C5000) and 399-3-18 (C4999). Results from these wells are being compiled and interpreted and will be available in forthcoming reports. All the new wells have been completed with 15-cm- (6-in.-) diameter casing and screens to support treatability testing; first routine sampling of these wells occurred in July 2006. 


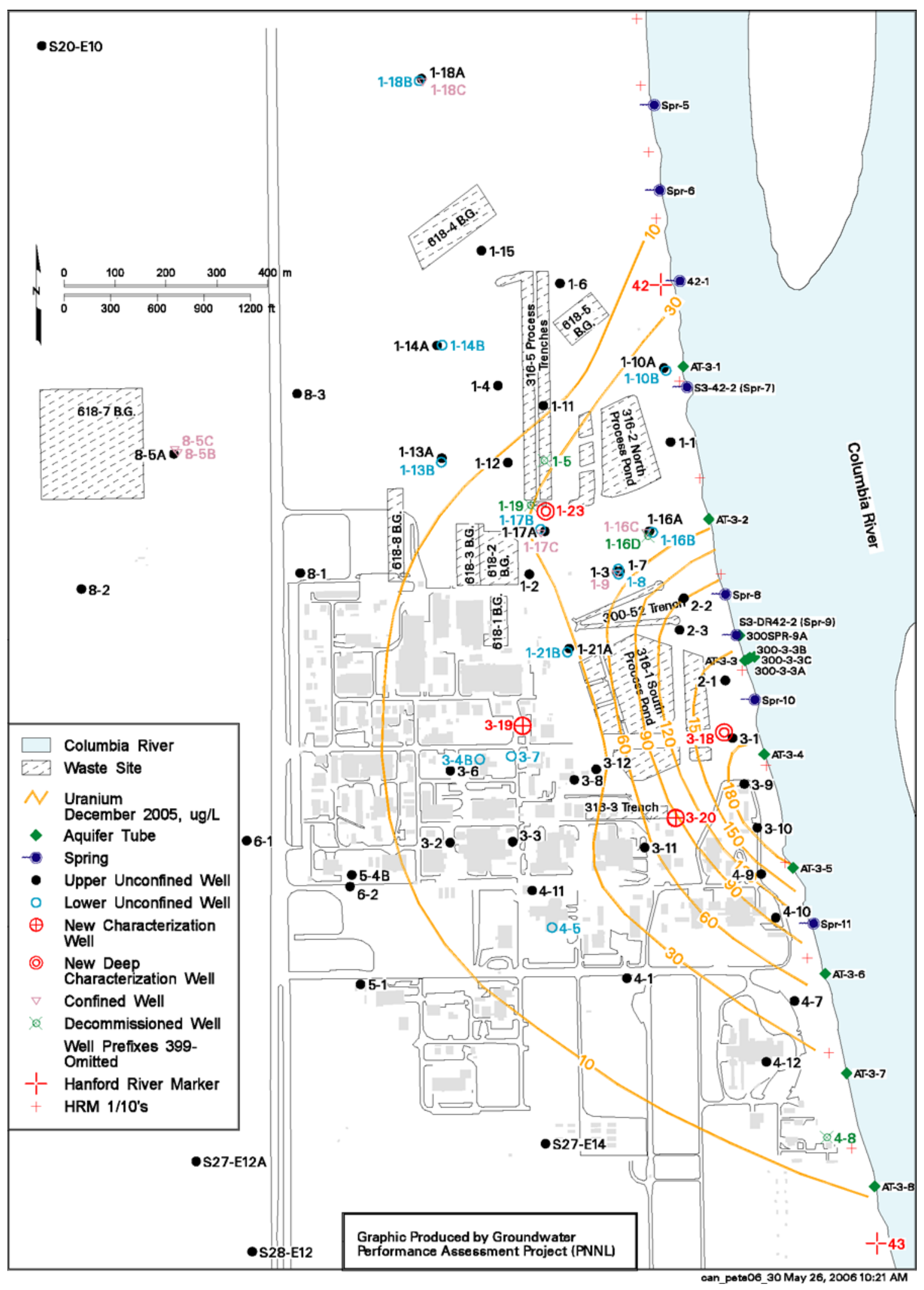

Figure 1. LFI Characterization Well Location Map 


\subsection{Public Involvement in 300 Area Groundwater Decisions}

Over the past 4 years, several public workshops have been held to discuss remedial action alternatives and future land use options for the Hanford 300 Area:

- June 2002 and May 2003: U.S. Environmental Protection Agency (EPA)-sponsored stakeholder workshops to discuss remedial action alternatives for the 300 Area uranium plume.

- May 2004: U.S. Department of Energy (DOE) Science and Technology Program open meeting with contractors and the public - Conceptual Model Development and Reactive Transport Modeling for the 300 Area Uranium Plume.

- August 2004: DOE Headquarters review and discussion of 300 Area uranium plume - Monitoring Optimization Technical Assistance Workshop.

- May 2005: DOE-sponsored stakeholder workshop to receive public input on remedial actions and future land use for the 300 Area - 300 Area End States Public Workshop.

- October 2005: DOE-sponsored stakeholder involvement workshop - 300-FF-5 Workshop and Tour: Progress of the Limited Field Investigation Supporting the Phase III Feasibility Study.

Input received from these workshops supports investigating remedial action technologies that are designed to reduce the concentrations of uranium in groundwater beneath the 300 Area such that the aquifer can be restored to its maximum beneficial use, i.e., as a resource for drinking water. Reducing concentrations in the aquifer will also reduce any potential risk to ecological receptors in the Columbia River.

\subsection{Polyphosphate Technology Description}

The use of soluble long-chain polyphosphate materials has been demonstrated to delay the precipitation of phosphate phases (Wellman et al. 2006). Precipitation of phosphate minerals occurs when phosphate compounds degrade in water, due to hydrolysis, to yield the orthophosphate molecule $\left(\mathrm{PO}_{4}{ }^{3-}\right)$. The longer the polyphosphate chain, the slower the hydrolysis reaction that leads to orthophosphate production. Accordingly, use of a long-chain polyphosphate compound does not result in a drastic change in hydraulic conductivity of the target aquifer.

Injection of a sodium tripolyphosphate amendment into the uranium-bearing saturated porous media has been shown to immobilize uranium through the formation of an insoluble uranyl phosphate mineral, autunite $\left\{\mathrm{X}_{1-2}\left[\left(\mathrm{UO}_{2}\right)\left(\mathrm{PO}_{4}\right)\right]_{2-1} \bullet n \mathrm{H}_{2} \mathrm{O}\right\}$, where $\mathrm{X}$ is any monovalent or divalent cation. Because autunite sequesters uranium in the oxidized form, $\mathrm{U}^{6+}$, rather than forcing reduction to $\mathrm{U}^{4+}$, the possibility of re-oxidation and subsequent re-mobilization of uranium is negated. Release of uranium from the autunite structure may only occur through dissolution of the autunite structure. Extensive testing demonstrates the very low solubility and slow dissolution kinetics of autunite under conditions relevant to the Hanford subsurface (Wellman et al. 2006). In addition to autunite, excess phosphorous may result in apatite mineral formation, providing a long-term source of treatment capacity. 


\subsection{Selection of the Treatability Test Site}

Well 399-1-23 (Well ID C5000) has been selected as the candidate well for performing the treatability test (Figure 2). This well is located at the southern end of a liquid waste disposal trench that is a known source for uranium. The well is sufficiently far inland from the river such that infiltration of river water during normal high discharge conditions does not reach the well, which if that occurred, would complicate interpretation of test results. This well was also selected because of its contaminant profile, i.e., it has a moderately thick ( $6.1 \mathrm{~m}$ [20 ft]) interval of contaminated permeable Hanford gravel below the water table which will not be impacted significantly by river level fluctuations. Depth-discrete uranium concentrations in groundwater samples collected during drilling in this well ranged up to $202 \mu \mathrm{g} / \mathrm{L}$ in the uppermost portion of the aquifer and drop off to below detection deep in the aquifer below the Hanford/Ringold contact. Hydraulic conductivity values also vary greatly above and below the contact as defined by depth discrete slug tests conducted as the borehole was advanced. Values above the

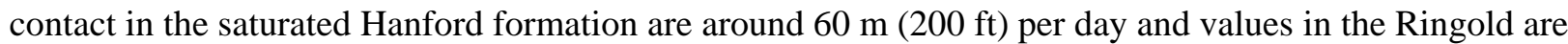

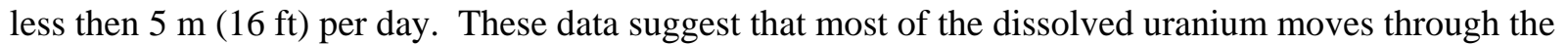
permeable interval above the Hanford/Ringold contact. Hydrogeologic interpretations of the continuous sediment core reinforce this interpretation. There is also a strong indication that the deep vadose interval just above the water table is contaminated with low levels of process uranium which maybe contributing to groundwater contamination levels. These characterization results are plotted on the composite log for well 399-1-23 (Figure 3).

\subsection{Scope}

This site characterization plan covers work elements associated with site-specific characterization of the polyphosphate treatability test site. A schedule showing the timing of these work elements in relation to bench scale testing and planning/implementation of the polyphosphate injection test is provided in Figure 4. Planned activities include (1) monitoring well installation, (2) site setup, (3) collection of baseline groundwater chemistry samples, (4) hydraulic testing to obtain formation hydraulic properties, (5) EBF testing to assess the vertical distribution of horizontal hydraulic conductivity (i.e., vertical heterogeneities), and (6) a conservative tracer injection test. The tracer test will be used to further evaluate formation heterogeneities, to assess the downgradient transport of the tracer plume (i.e., aquifer transport properties), to refine the polyphosphate injection design, and to test operational procedures. All characterization activities will be conducted in accordance with applicable Pacific Northwest National Laboratory (PNNL) procedures (PNL-MA-567; PNNL 1994) and any investigation derived waste will be handled in accordance with Hanford Site requirements.

\subsection{Well Installation}

Five to eight monitoring wells will be installed within the 300-FF-5 Operable Unit, near well 399-123, which is located in the southeastern portion of the Hanford Site (Figures 1 and 2). Up to five of the monitoring wells will be installed for operational monitoring (i.e., to monitor the initial injection pore volume of tracer, and ultimately, the polyphosphate solution) and will be installed within a radial distance of $9.1 \mathrm{~m}$ (30 ft) from the selected treatability test injection well (399-1-23). Up to three additional monitoring wells will be installed farther downgradient of the test site to monitor downgradient transport 


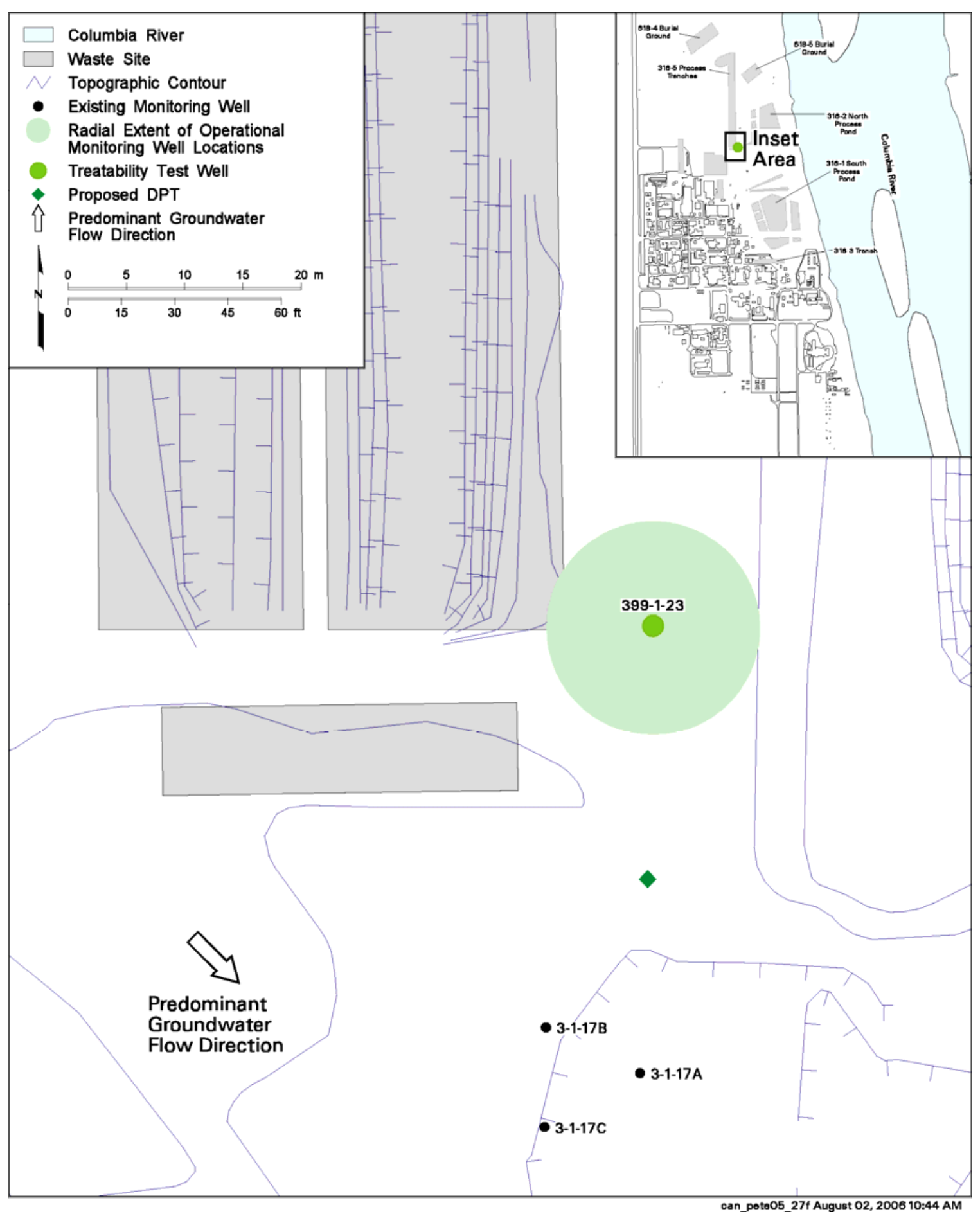

Figure 2. Polyphosphate Treatability Test Site Location, 300-FF-5 Operable Unit, 300 Area 


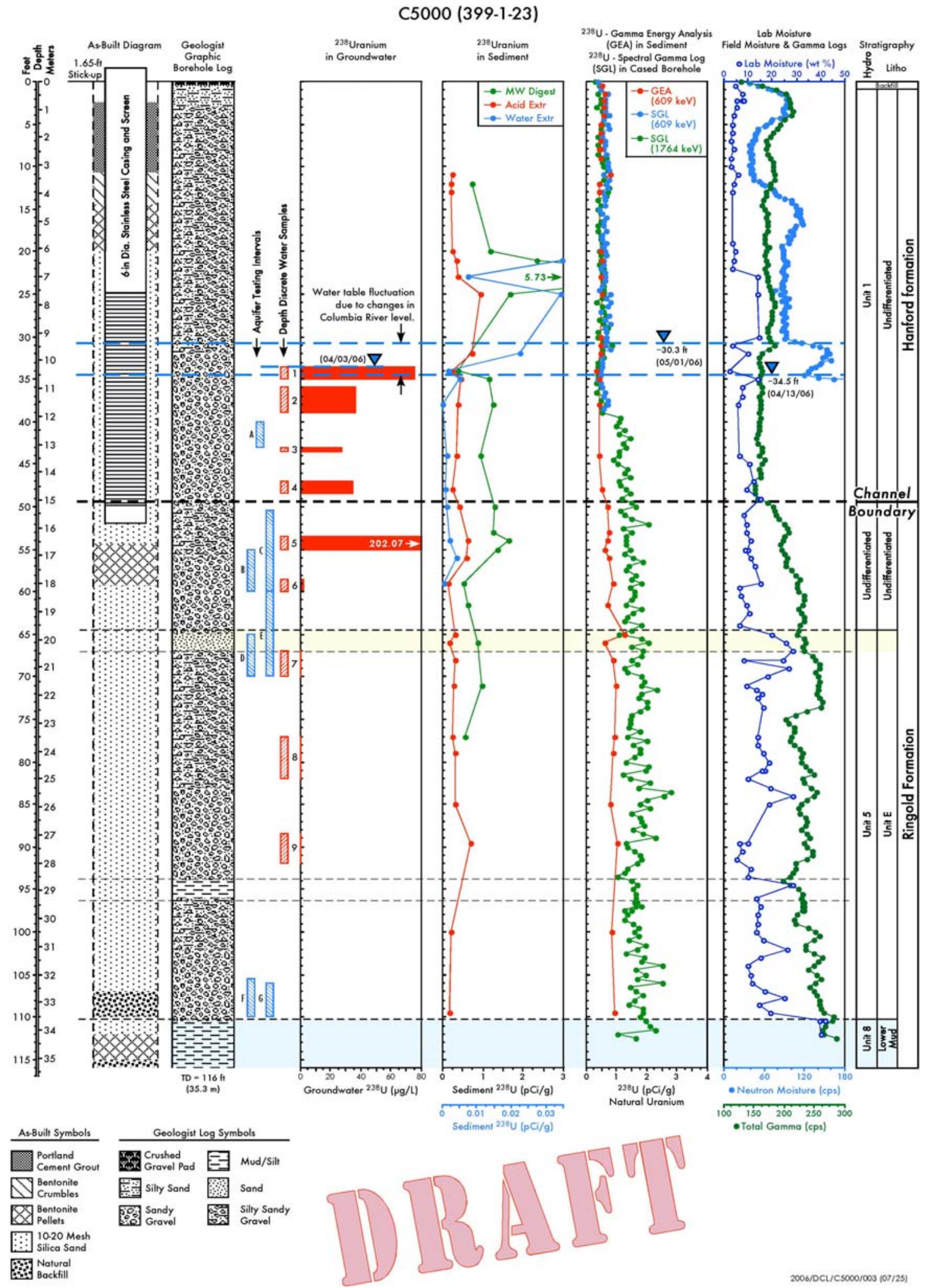

Figure 3. Composite Log for LFI Well 399-1-23 


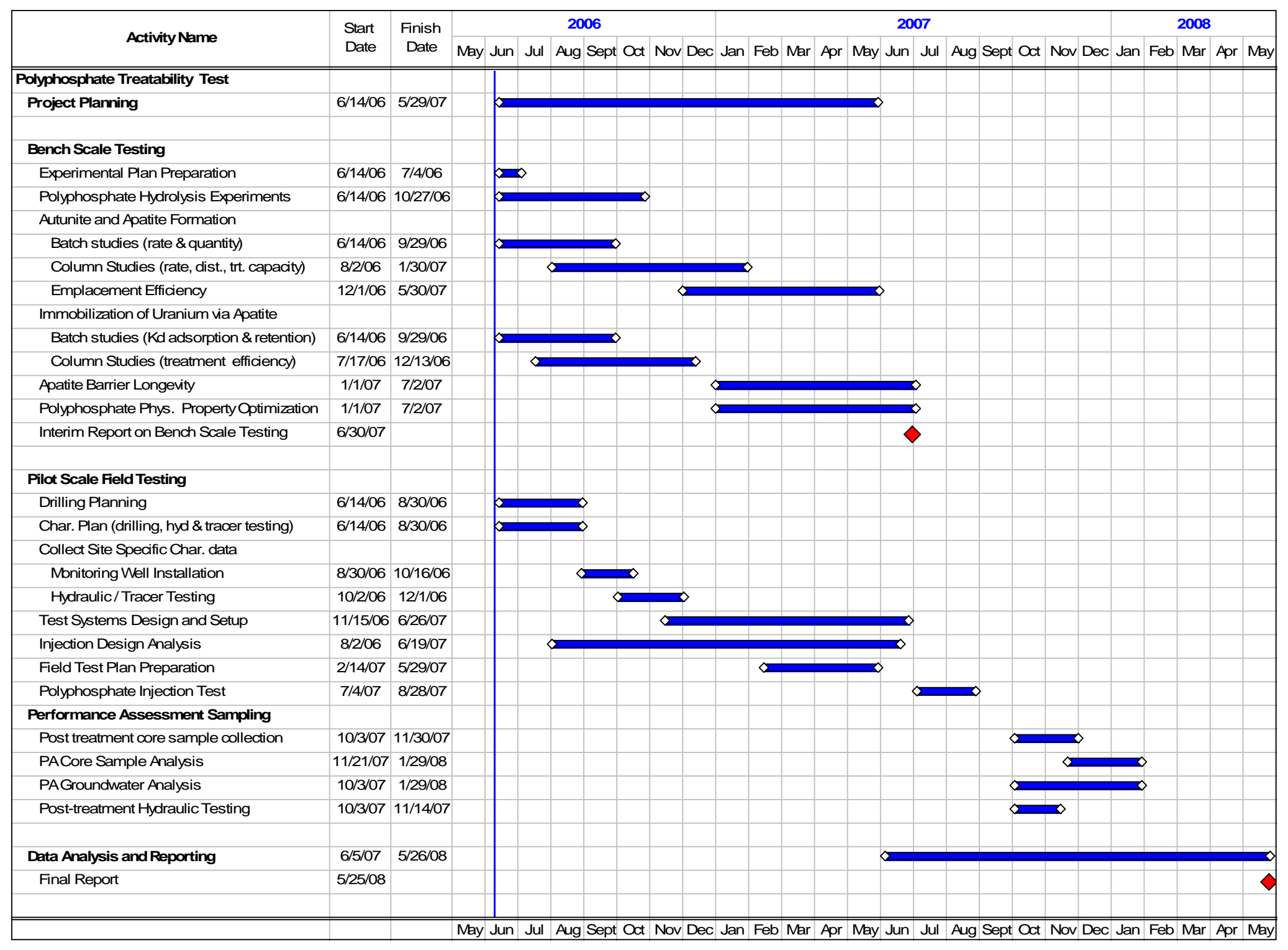

Figure 4. Polyphosphate Treatability Test Project Schedule 
of the polyphosphate reagent and assess downgradient performance of the amendment. Because insufficient bench-scale development work has been completed to determine appropriate downgradient well locations, these wells will be installed during a second drilling campaign, which will occur once initial site characterization activities have been completed and preliminary bench-scale results are available.

Based on the current conceptual understanding of the test site location and available budget for well installation, operational monitoring wells will consist of a two wells monitoring discrete intervals of the aquifer, one over the top portion and one over the bottom portion of the aquifer, and the other three

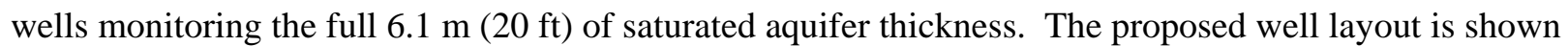
in Figure 5.

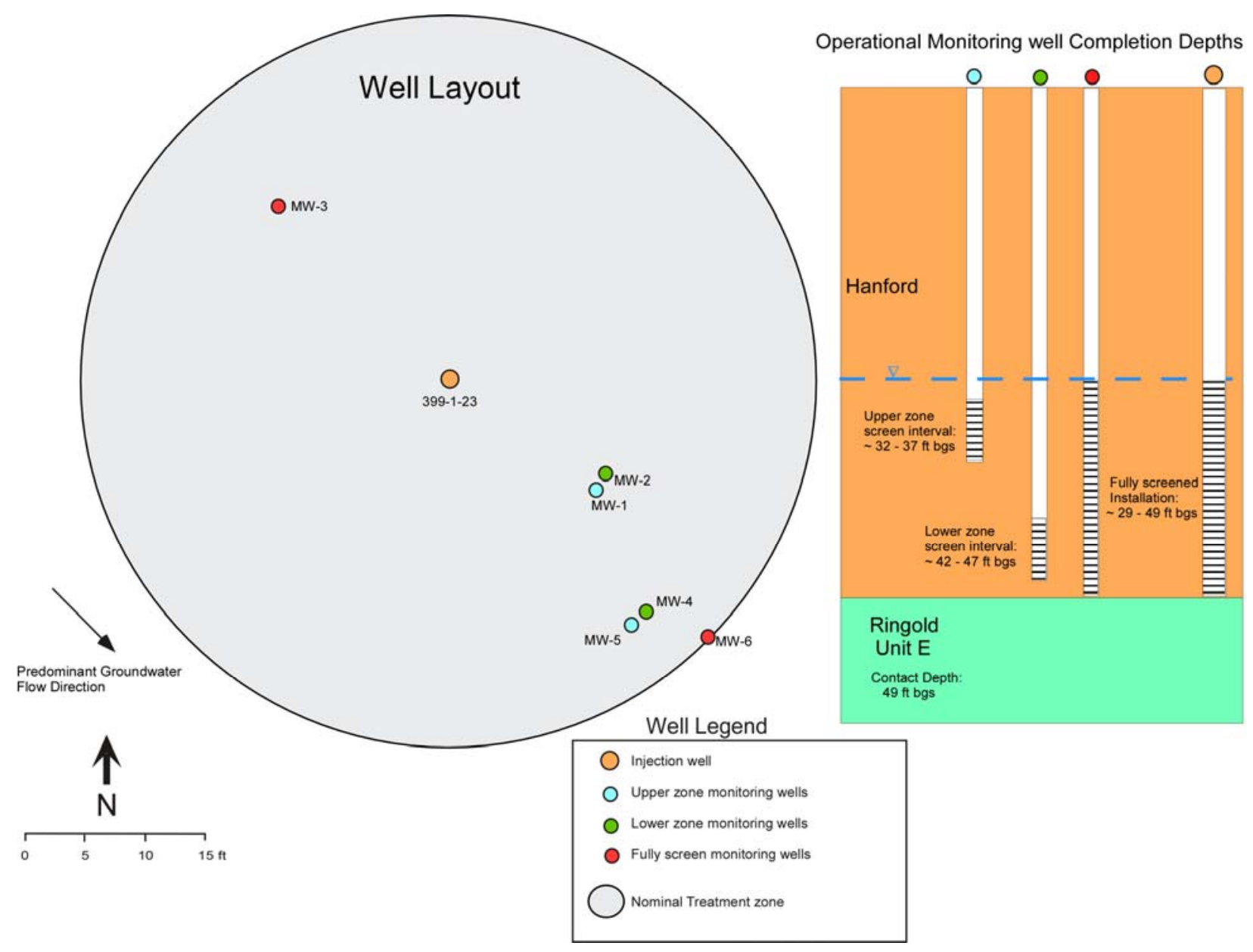

Figure 5. Polyphosphate Treatability Test Site Well Layout 
Due to extensive depth-discrete characterization that was conducted during the installation of well 399-1-23, only limited additional characterization will be conducted as these boreholes are advanced. At a minimum, a detailed lithologic description will be provided by the well site geologist from ground surface to total depth. This description will include (1) drilling conditions and changes in drilling conditions (e.g., drilling method, drill rate, addition of fluids, heaving sand); (2) depths and types of all collected samples; (3) lithologic descriptions of sediments, including relative moisture; (4) results of radiation and chemical monitoring of sediments; and (5) water level.

If the collection of sediment grab samples does not significantly impact overall well installation cost, samples may be collected as required to support bench-scale testing. Sediment grab samples would be collected over depth intervals of interest and at changes in lithology or at depths where unusual conditions are encountered (as determined by the field geologist). Samples would be collected in pint or quart glass jars capable of sealing existing moisture in the sample for a reasonable time period. If representative samples cannot be collected (e.g., if large particles do not fit in the container), notes describing the condition of the sample will be put in the geologist's log. All sediment samples that are collected will be labeled (well number and depth), and (if appropriate) radiation released. Chip tray samples will be collected at regular intervals, with additional samples as required to adequately characterized changes in lithology, over the full depth interval of the borehole.

As with sediment sampling, geophysical logging will only be conducted if it does not significantly impact overall well installation cost. Subsurface spectral gamma geophysical logging may be conducted based on contractor availability and the potential for impact to the drilling schedule. Geophysical logging would be conducted by others over the total drill depth for identification of contaminants, site characterization, stratigraphic correlation, and selection of final screen placement. Anomalous or unusual readings may be re-logged as necessary.

Well casings and screens will be composed of either PVC or stainless steel. Well screens will consist of $\mathrm{V}$-wire continuous wire wrap screen to prevent clogging. All casing and screen material will be either 5- or 10-cm (2- or 4-in.) nominal diameter. Monitoring well screens will be 20-slot and the filter pack composed of 10- to 20-mesh silica sand. Bentonite well seals will be completed in such a manner as to isolate the seal from leaking or migrating into the screen interval. Fluor Hanford, Inc. shall determine the placement depths (at the direction of PNNL) and type of sealing materials to be used during the construction. The well construction shall meet the WAC 173-160 requirements.

\subsection{Site Setup}

This section includes a description of the site utilities, monitoring equipment, analytical equipment, injection equipment, and the integration of these components into the operational systems required to conduct the work elements included in this characterization plan. PNNL will work with Fluor Hanford, Inc. to arrange for access to available site utilities. PNNL will provide all operational and monitoring equipment required to conduct the work elements included in this characterization plan. 


\subsubsection{Site Utilities}

Site utility requirements for these work elements includes access to electrical power, water supply, and wastewater disposal.

\subsubsection{Water Supply}

To conduct the tracer injection test, and potentially a constant rate injection test to better quantify hydraulic properties, a substantial source of water is needed to make up the injection solutions. It is estimated that the tracer injection test will require up to 38,000 L (100,000 gal) of water at rates as high as $760 \mathrm{~L} / \mathrm{m}$ (200 gpm). If a pressurized raw or potable water supply is not available onsite, groundwater could be withdrawn from wells prior to the test and stored in onsite storage tanks until the injection tests are conducted. Alternatively, a nearby uncontaminated well could be used to supply injection on demand, eliminating the need for the storage of large volumes of groundwater. If available, a nearby fire hydrant or other pressurized water source could be utilized. Static pressure at the point of connection should be $\sim 60$ psi. In the event that no water quality assessments have been performed on an available water source and they are deemed necessary, water samples will be submitted for anions, trace metals, and residual chlorine analysis. This option would have to be evaluated to assure that injection water characteristics will not significantly impact aquifer geochemistry such that performance assessment of the technology is compromised.

\subsubsection{Electrical Service}

Electrical power is required to operate site facilities, including a mobile laboratory and associated analytical equipment and injection/monitoring equipment. Site power can be supplied by appropriately sized generators; however, line power is preferable because, once installed, it is virtually maintenance free and more reliable than generators.

\subsubsection{Wastewater Disposal}

PNNL will work with Fluor Hanford, Inc. to arrange for the transport and appropriate disposal of all investigation derived waste.

\subsubsection{Monitoring Equipment}

\subsubsection{Sampling Pumps}

Dedicated Grundfos RediFlo2 sampling pumps or comparable will be installed in all site monitoring wells. The sample tubing from each of these sampling pumps will be routed inside an onsite mobile laboratory and connected directly to a sampling manifold. In the event RediFlo2 pumps are used, sample pumps will be operated using a manufacturer-supplied variable-speed control box (converts standard $110-\mathrm{V}$ single-phase power into three-phase power to meet the requirements of RediFlo2 sampling pumps) and a project-developed multichannel interface (pump switch box) that allows multiple sample pumps to be operated using a single control box. If a different type of sampling pump is used, a comparable 
multichannel switchbox will be developed to facilitate efficient high frequency sampling of multiple monitoring wells.

\subsubsection{Sampling Manifold}

A sampling manifold will be used that allows all sampling streams to be routed into a central flow cell for monitoring field parameters and sampling port for the collecting groundwater samples. The advantage of this type of system is that all field parameter measurements are made using a single set of electrodes, which improves data quality and comparability of spatially distributed measurements.

Consistent labeling between the sampling manifold and pump switch box simplifies selection of the well to be sampled and reduces the chance of operator error during the frequent sampling associated with the injection tests.

\subsubsection{Field Parameter Measurements}

Field parameters will be monitored using $\mathrm{pH}$, oxidation-reduction potential (ORP), temperature, specific conductance (SpC), and dissolved oxygen (DO) electrodes installed in a flow-through monitoring assembly. The flow-through assembly has been designed to minimize the amount of "dead space” within the monitoring chamber and results in flow-through residence times of less than three seconds under standard monitoring conditions. Purge volumes pumped prior to sample collection will be determined by monitoring stabilization of field parameters. The field parameter monitoring electrodes that will be used during this field test will meet the specifications shown in Section 4.

\subsubsection{Water-Level/Pressure Response Measurements}

Pressure transducers (10 and 20 psi, $0.1 \%$ of full-scale accuracy) will be installed in selected wells to monitor pressure response during hydraulic and tracer injection tests and continuously recorded using a Campbell Scientific CR10 datalogger, or comparable. Transducer readings will be validated periodically with water-level measurements to check for transducer drift. Water levels will be measured using a highaccuracy, National Institute of Standards and Technology traceable, non-stretch, metal-taped, water-level meter marked in 0.03.04-cm (0.01-ft) gradations.

\subsubsection{Injection and Withdrawal Equipment}

\subsubsection{Injection Manifold}

The injection manifold consists of an injection pump and appropriately routed piping, valving, and flow rate monitoring equipment. The manifold is used to control (both rate and concentration), monitor, and sample the injection solutions. The manifold will be constructed of 316 stainless steel and will use stainless steel ball valves for both diversion/shutoff and flow control valves.

\subsubsection{Injection Pump}

A 0.75 horse power (hp) Grundfos stainless steel multi-stage centrifugal pump (Model \# CRN2-30) or comparable will be used for injecting the concentrated solution. The injection tubing that extends from 
the well head to the center of the injection interval will be constructed of appropriately sized stainless steel or PVC pipe.

\subsubsection{Turbine Flow-Meters}

Omega turbine flow meters will used to measure the flow rate of the various streams and the total injection flow rate. Depending on the design injection rate, either a 2.5- or 5.0-cm (1- or 2-in.) diameter flow meter will be used to monitor the dilution water and total injection rate and a 2.5-cm (1-in.) diameter flow meter will be used to monitor the injection rate of the concentrated reagent solutions. These flow meters will be continually logged with a Campbell Scientific CR10 datalogger.

\subsubsection{Submersible Extraction Pump}

An appropriately sized stainless steel submersible will be used as the extraction pump if groundwater is used as the water supply. The extraction pump will be installed on an appropriately sized stainless steel riser.

\subsubsection{Description of Equipment Integration/Operation}

Following is a description of how the various equipment components are integrated into the systems required to conduct the tracer injection test (and any constant rate injection testing, if required) and collect groundwater samples from the polyphosphate treatability test site.

\subsubsection{Injection Testing}

All injection testing will be conducted using the equipment described above. The desired injection concentration will be achieved by mixing the concentrated tracer solutions with dilution water from the pressurized source. Injection pressure for the concentrated solutions and dilution water will be provided by the stainless steel injection pump and the pressurized water supply (e.g., fire hydrant or downhole extraction pump), respectively. The two injection streams will be mixed within the injection manifold before the solution arrives at the point of injection (i.e., the center of the injection well's screen interval).

All injection flow rates (concentrated solution, dilution water, total) will monitored with turbine flow meters and controlled by manually adjusting flow control valves. Sample ports will be located on the manifold so that samples of the concentrated and injection solutions can be collected throughout the injection test.

\subsubsection{Groundwater Sample Collection}

Groundwater sample collection will be conducted using the equipment described above. The groundwater sampling equipment consists of dedicated variable-speed submersible sampling pumps installed in all site monitoring wells with sample tubing and control wiring routed to a central location inside the onsite mobile laboratory where groundwater field parameters are monitored (in a flow-through cell) and groundwater samples are collected. 
The procedure for monitoring field parameters and collecting groundwater samples using this equipment is described below:

1. Select well to be sampled on pump switch box and sampling manifold.

2. Start pump at predetermined purge rate ( $\sim 4$ to $12 \mathrm{~L}$ [ 1 to 3 gal] per minute).

3. Following displacement of any air bubbles trapped in the sample tubing (generally within the first 20 to 30 seconds), divert 2 to $4 \mathrm{~L}$ ( 0.5 to 1 gal) per minute of sample stream to flow-through cell.

4. Monitor field parameters until they have stabilized.

5. Record field parameter measurements in field log book or project-specific data sheets and collect required groundwater samples.

6. Select next well to be sampled and repeat process.

\subsection{Baseline Groundwater Chemistry}

From two to three sets of groundwater chemistry samples will be collected from site monitoring wells and submitted for analysis to establish baseline conditions, prior to the tracer test and emplacement of the polyphosphate amended treatment zone. Sampling and analytical equipment used for this activity will be capable of measuring the specific analytes indicated in Section 4, Table 1.

\subsection{Hydraulic Testing}

Hydraulic tests will be conducted in the injection well and monitoring wells, as required, to determine the hydraulic properties of the aquifer and the specific capacity of the injection well. Due to investigation derived waste disposal limitations, this initial hydraulic testing will be limited to a step injection test to determine the specific capacity of the injection well and either slug interference testing or a short duration constant-rate injection test to provide a semi-quantitative estimate of hydraulic properties. Pressure recovery data from the tracer injection test may also be analyzed if the slug interference test and/or short duration constant-rate injection test does not provide sufficient data for a good quantitative estimate of hydraulic properties. These test data will be representative of baseline (pre-injection) aquifer conditions and will be incorporated into the design analysis of the pilot technology demonstration. Hydrologic test data will be analyzed using peer reviewed analytical or numerical methods that are applicable to the given test conditions.

In addition to these standard aquifer testing methods, electromagnetic borehole flowmeter tests may be conducted to assess the vertical distribution of horizontal hydraulic conductivity. Although one test was conducted in well 399-1-23 immediately following the LFI drilling activities, additional testing may be conducted in the newly installed monitoring wells to evaluate the spatial distribution of vertical variability. 


\subsection{Tracer Injection Test}

The objective of the tracer test is to further evaluate formation heterogeneities, to assess the downgradient transport of the tracer plume (i.e., aquifer transport properties), to refine the polyphosphate injection design, and to test operational procedures. This tracer test will provide information on the effective porosity of the aquifer at the treatability test site and arrival times at the monitoring wells. The effective porosity will help determine the volumes of polyphosphate solution required. The arrival curves will help design the sampling frequency needed for each monitoring well for the polyphosphate injection test. An additional benefit of the tracer test is to help test equipment operation and procedures needed for the polyphosphate injection test.

A solution containing the conservative tracer, potassium or sodium bromide ( $\sim 80 \mathrm{ppm} \mathrm{Br})^{-}$), will be prepared and injected into the central injection well shown on Figure 5. A tracer volume will be used that assures arrival at all operational monitoring wells. Bromide concentrations will be measured in the surrounding monitoring wells and breakthrough curves (time vs. concentration) will be prepared for each well. The volume of tracer solution required, which will be similar to the nominal injection planned for the polyphosphate injection test, will depend on the targeted treatment zone thickness and planned radial extent.

Bromide concentrations will be measured using ion-specific electrodes at the field site. Archive samples will also be collected and submitted to PNNL laboratories for verification by ion chromatography. A detailed discussion of analytical requirements is provided in Section 4.

\subsection{Sampling and Analysis}

Groundwater sampling will be conducted during site-specific characterization of the polyphosphate treatability test site. All sampling will be conducted in accordance with applicable PNNL procedures (PNL-MA-567; PNNL 1994) and the following sampling and analysis requirements. Investigation derived waste will be handled in accordance with Hanford Site requirements.

As indicated in Section 3, groundwater samples will be collected and submitted for laboratory analysis during two of the planned work elements: baseline groundwater chemistry sampling and aqueous sample collection during and following the tracer injection test. During both types of sampling, field parameters ( $\mathrm{pH}, \mathrm{SpC}, \mathrm{DO}, \mathrm{ORP}$, and $\mathrm{T}$ ) will be measured and recorded manually on data sheets which will be copied for distribution. Calibration of field probes will follow the manufacturer's instructions and applicable PNNL procedures (PNL-MA-567) using standard calibration solutions. Detailed sampling instructions, including which wells to sample and at what frequency, will be posted in the field laboratory prior to initiation of the test.

Sample collection requirements for baseline groundwater chemistry determination and observational monitoring for the tracer injection test are provided in Table 1 and Table 2, respectively. During baseline sampling, all available test site monitoring wells will be sampled to determine baseline conditions. During the tracer injection test, samples will be collected with sufficient frequency to adequately describe tracer arrivals curves at the various operational monitoring points. All analyses will be performed in accordance with the guidelines set forth in Table 3. 
Table 1. Baseline Groundwater Chemistry Sampling Requirements

\begin{tabular}{|c|c|c|c|c|c|}
\hline Parameter & $\begin{array}{l}\text { Media/ } \\
\text { Matrix }\end{array}$ & Sampling Frequency & $\begin{array}{l}\text { Volume/ } \\
\text { Container }\end{array}$ & Preservation & $\begin{array}{l}\text { Holding } \\
\text { Time }\end{array}$ \\
\hline $\begin{array}{l}\text { Major Cations: } \\
\mathrm{Al}, \mathrm{As}, \mathrm{B}, \mathrm{Ba}, \mathrm{Bi}, \mathrm{Ca} \text {, } \\
\mathrm{Co}, \mathrm{Fe}, \mathrm{K}, \mathrm{Mg}, \mathrm{Mn}, \mathrm{Ni}, \\
\mathrm{Zn}, \mathrm{Zr}, \mathrm{P}, \mathrm{Sr}, \mathrm{Na}, \mathrm{Si}, \mathrm{S} \text {, } \\
\text { Sb }\end{array}$ & Water & $\begin{array}{l}\text { Two to three baseline } \\
\text { sampling events }\end{array}$ & $\begin{array}{l}20 \text {-ml plastic } \\
\text { vial }\end{array}$ & $\begin{array}{c}\text { Filtered, } \\
\mathrm{HNO}_{3} \text { to } \mathrm{pH}<2\end{array}$ & 60 Days \\
\hline $\begin{array}{l}\text { RCRA/Trace Metals: } \\
\mathrm{Cr}, \mathrm{Cu}, \mathrm{As}, \mathrm{Se}, \mathrm{Mo}, \mathrm{Ag}, \\
\mathrm{Cd}, \mathrm{Pb},{ }^{238} \mathrm{U}\end{array}$ & Water & $\begin{array}{l}\text { Two to three baseline } \\
\text { sampling events }\end{array}$ & $\begin{array}{l}20 \text {-ml plastic } \\
\text { vial }\end{array}$ & $\begin{array}{c}\text { Filtered, } \\
\mathrm{HNO}_{3} \text { to } \mathrm{pH}<2\end{array}$ & 60 Days \\
\hline $\begin{array}{l}\text { Anions: } \mathrm{Cl}^{-}, \mathrm{Br}^{-}, \mathrm{SO}_{4}{ }^{2-} \text {, } \\
\mathrm{PO}_{4}{ }^{3-}, \mathrm{NO}_{2}{ }^{-}, \mathrm{NO}_{3}{ }^{-}\end{array}$ & Water & $\begin{array}{l}\text { Two to three baseline } \\
\text { sampling events }\end{array}$ & $\begin{array}{l}20 \text {-ml plastic } \\
\text { vial }\end{array}$ & $\mathrm{Cool} 4^{\circ} \mathrm{C}$ & 45 Days \\
\hline $\mathrm{pH}$ & Water & $\begin{array}{l}\text { Monitored during each } \\
\text { sampling event }\end{array}$ & $\begin{array}{l}\text { Field } \\
\text { Measurement }\end{array}$ & None & N/A \\
\hline Specific Conductance & Water & $\begin{array}{l}\text { Monitored during each } \\
\text { sampling event }\end{array}$ & $\begin{array}{l}\text { Field } \\
\text { Measurement }\end{array}$ & None & N/A \\
\hline Dissolved Oxygen & Water & $\begin{array}{l}\text { Monitored during each } \\
\text { sampling event }\end{array}$ & $\begin{array}{l}\text { Field } \\
\text { Measurement }\end{array}$ & None & N/A \\
\hline $\begin{array}{l}\text { Oxidation-Reduction } \\
\text { Potential }\end{array}$ & Water & $\begin{array}{l}\text { Monitored during each } \\
\text { sampling event }\end{array}$ & $\begin{array}{l}\text { Field } \\
\text { Measurement }\end{array}$ & None & N/A \\
\hline Temperature & Water & $\begin{array}{l}\text { Monitored during each } \\
\text { sampling event }\end{array}$ & $\begin{array}{l}\text { Field } \\
\text { Measurement }\end{array}$ & None & N/A \\
\hline
\end{tabular}

Table 2. Tracer Injection Test Sampling Requirements

\begin{tabular}{|c|c|c|c|c|c|}
\hline Parameter & $\begin{array}{l}\text { Media/ } \\
\text { Matrix }\end{array}$ & Sampling Frequency & $\begin{array}{l}\text { Volume/ } \\
\text { Container }\end{array}$ & Preservation & $\begin{array}{l}\text { Holding } \\
\text { Time }\end{array}$ \\
\hline Anions: $\mathrm{Br}^{-}$ & Water & $\begin{array}{l}\text { Determined based on } \\
\text { predicted tracer arrivals }\end{array}$ & $\begin{array}{l}20-m l \text { plastic } \\
\text { vial }\end{array}$ & $\mathrm{Cool} 4^{\circ} \mathrm{C}$ & 45 Days \\
\hline $\mathrm{Br}^{-}$Field Screening & Water & $\begin{array}{l}\text { Determined based on } \\
\text { predicted tracer arrivals }\end{array}$ & \begin{tabular}{|l} 
Field \\
Measurement
\end{tabular} & None & N/A \\
\hline $\mathrm{pH}$ & Water & $\begin{array}{l}\text { Monitored during each } \\
\text { sampling event }\end{array}$ & \begin{tabular}{|l} 
Field \\
Measurement
\end{tabular} & None & N/A \\
\hline Specific Conductance & Water & $\begin{array}{l}\text { Monitored during each } \\
\text { sampling event }\end{array}$ & \begin{tabular}{|l} 
Field \\
Measurement
\end{tabular} & None & N/A \\
\hline Dissolved oxygen & Water & $\begin{array}{l}\text { Monitored during each } \\
\text { sampling event }\end{array}$ & \begin{tabular}{|l|} 
Field \\
Measurement \\
\end{tabular} & None & N/A \\
\hline $\begin{array}{l}\text { Oxidation-Reduction } \\
\text { Potential }\end{array}$ & Water & $\begin{array}{l}\text { Monitored during each } \\
\text { sampling event }\end{array}$ & \begin{tabular}{|l} 
Field \\
Measurement
\end{tabular} & None & N/A \\
\hline Temperature & Water & $\begin{array}{l}\text { Monitored during each } \\
\text { sampling event }\end{array}$ & $\begin{array}{l}\text { Field } \\
\text { Measurement }\end{array}$ & None & N/A \\
\hline
\end{tabular}


Table 3. Analytical Requirements

\begin{tabular}{|c|c|c|c|c|}
\hline Parameter & Analysis Method & $\begin{array}{l}\text { Detection Limit or } \\
\text { (Range) }\end{array}$ & $\begin{array}{c}\text { Typical Precision/ } \\
\text { Accuracy }\end{array}$ & QC Requirements \\
\hline $\begin{array}{l}\text { Major Cations/Metals: } \\
\mathrm{Ca}, \mathrm{Fe}, \mathrm{K}, \mathrm{Mg}, \mathrm{P}, \mathrm{Na}, \mathrm{Si} \text {, } \\
\mathrm{S} \\
\mathrm{Al}, \mathrm{B}, \mathrm{Ba}, \mathrm{Bi}, \mathrm{Ni}, \mathrm{Zn}, \mathrm{Zr} \text {, } \\
\mathrm{Sr}\end{array}$ & $\begin{array}{l}\text { ICP-OES, PNNL- } \\
\text { AGG-ICP-AES } \\
\text { (similar to EPA } \\
\text { Method 6010B) }\end{array}$ & $\begin{array}{l}1 \mathrm{mg} / \mathrm{L} \\
0.1 \mathrm{mg} / \mathrm{L}\end{array}$ & $\pm 10 \%$ & $\begin{array}{l}\text { Daily calibration; blanks } \\
\text { and duplicates and } \\
\text { matrix spikes at } 10 \% \\
\text { level per batch of } 20 \text {. }\end{array}$ \\
\hline $\begin{array}{l}\text { RCRA / Trace Metals: } \\
\mathrm{Cr}, \mathrm{Cu}, \mathrm{As}, \mathrm{Se}, \mathrm{Mo}, \mathrm{Ag} \\
\mathrm{Cd}, \mathrm{Pb},{ }^{238} \mathrm{U}\end{array}$ & $\begin{array}{l}\text { ICP-MS, PNNL- } \\
\text { AGG-415 (similar } \\
\text { to EPA Method } \\
6020 \text { ) }\end{array}$ & $\begin{array}{l}1 \mu \mathrm{g} / \mathrm{L} \text { for trace } \\
\text { elements }\end{array}$ & $\pm 10 \%$ & $\begin{array}{l}\text { Daily calibration; blanks } \\
\text { and duplicates and } \\
\text { matrix spikes at } 10 \% \\
\text { level per batch of } 20 \text {. }\end{array}$ \\
\hline $\begin{array}{l}\text { Anions: } \mathrm{Cl}^{-}, \mathrm{Br}^{-}, \mathrm{SO}_{4}{ }^{2-} \\
\mathrm{PO}_{4}{ }^{3-}, \mathrm{NO}_{2}^{-}, \mathrm{NO}_{3}^{-}\end{array}$ & $\begin{array}{l}\text { Ion Chromato- } \\
\text { graphy, AGG-IC- } \\
001 \text { (based on EPA } \\
\text { Method 300.0A) } \\
\end{array}$ & $1 \mathrm{mg} / \mathrm{L}$ & $\pm 15 \%$ & $\begin{array}{l}\text { Daily calibration; blanks } \\
\text { and duplicates at } 10 \% \\
\text { level per batch of } 20 \text {. }\end{array}$ \\
\hline $\mathrm{Br}^{-}$Field screening & $\begin{array}{l}\text { Ion selective } \\
\text { electrode }\end{array}$ & $(0.4$ to $79,900 \mathrm{mg} / \mathrm{L})$ & For indication only & $\begin{array}{l}\text { Follow manufacturer } \\
\text { recommendations }\end{array}$ \\
\hline $\mathrm{pH}$ & $\mathrm{pH}$ electrode & (2 to 12 units) & $\pm 0.2 \mathrm{pH}$ unit & $\begin{array}{l}\text { User calibrate, follow } \\
\text { manufacturer } \\
\text { recommendations }\end{array}$ \\
\hline Specific conductance & Electrode & (0 to $100 \mathrm{mS} / \mathrm{cm})$ & $\pm 1 \%$ of reading & $\begin{array}{l}\text { User calibrate, follow } \\
\text { manufacturer } \\
\text { recommendations }\end{array}$ \\
\hline Dissolved oxygen & $\begin{array}{l}\text { Membrane } \\
\text { electrode }\end{array}$ & (0 to $20 \mathrm{mg} / \mathrm{L}$ ) & $\pm 0.2 \mathrm{mg} / \mathrm{L}$ & $\begin{array}{l}\text { User calibrate, follow } \\
\text { manufacturer } \\
\text { recommendations }\end{array}$ \\
\hline $\begin{array}{l}\text { Oxidation-Reduction } \\
\text { Potential }\end{array}$ & Electrode & (-999 to $999 \mathrm{mV})$ & $\pm 20 \mathrm{mV}$ & $\begin{array}{l}\text { User calibrate, follow } \\
\text { manufacturer } \\
\text { recommendations }\end{array}$ \\
\hline Temperature & Thermocouple & $\left(-5\right.$ to $\left.50^{\circ} \mathrm{C}\right)$ & $\pm 0.2^{\circ} \mathrm{C}$ & Factory calibration \\
\hline \multicolumn{5}{|c|}{$\begin{array}{l}\text { ICP = Inductively coupled plasma. } \\
\text { OES = Optical emission spectrometry. } \\
\text { MS = Mass spectrometry. }\end{array}$} \\
\hline
\end{tabular}

\subsection{Data Recording/Management/Reporting}

Drilling, well completion, and sampling activities shall be recorded on the applicable procedural forms or logbooks and maintained in the field files by Fluor Hanford, Inc. (drilling and well completion) and PNNL project personnel. Upon completion of all activities, the field file custodian shall transmit a copy of all well drilling, completion, development, and sampling documentation to PNNL for inclusion in the project files.

For the hydraulic and tracer injection testing, a project-specific database will be developed and maintained to collect, organize, store, verify/validate, and manage analytical laboratory data and/or field 
measurements for collected samples. The data will be stored electronically in Microsoft Excel spreadsheets and paper copies will be maintained in the project files.

Data collected during these site characterization activities will be reported in a milestone report documenting results of the polyphosphate treatability test. The final report will cover activities ranging from basic laboratory development work through the field-scale demonstration of the technology. Findings presented in the final report will form the basis for an evaluation of this technology for full-scale implementation during the 300-FF-5 feasibility study.

\subsection{Health and Safety Training Requirements}

All personnel working within site control zones must comply with the Occupational Safety and Health Administration (OSHA) regulations as defined in 29 CFR 1910. In addition to other requirements, these regulations require all onsite personnel to receive a minimum of 40 hours training in health and safety for hazardous waste operations. In addition, the same personnel must be enrolled in a yearly medical surveillance program that includes a medical examination and work history review with special emphasis on symptoms related to the handling of hazardous substances and the fitness for duty. Personnel shall be certified as medically qualified to perform hazardous field activities or equivalent. Field personnel must successfully pass an annual respirator fit test, conducted in accordance with OSHA regulations, for the respiratory device(s) they will use. Supervisors must have received first aid/CPR training and attended the 8-hour supervisor's course. Additional relevant health and safety requirements specified in the drilling specific site health and safety plan developed by Fluor Hanford, Inc. will also be followed by PNNL project personnel when on site.

All pre-drilling planning, waste management, purgewater management, health and safety, and overall risk management will be the responsibility of Fluor Hanford, Inc., DOE's drilling contractor. All drill site activities will be managed by Fluor Hanford, Inc. with technical oversight provided by PNNL.

\subsection{References}

29 CFR 1910. “Occupational Safety and Health Standards.” U.S. Department of Labor, Code of Federal Regulations.

DOE. 1995. Remedial Investigation/Feasibility Study Report for the 300-FF-5 Operable Unit. DOE/RL-94-85, Rev. 0, U.S. Department of Energy, Richland, Washington.

DOE. 2006. 300-FF-5 Operable Unit Limited Field Investigation Plan. DOE/RL-2005-47, Rev. 1, U.S. Department of Energy, Richland, Washington. 
EPA. 1996. Record of Decision for the USDOE Hanford 300-FF-1 and 300-FF-5 Operable Units Remedial Actions. EPA/ROD/R10-96/143, U.S. Environmental Protection Agency, Region 10, Seattle, Washington.

EPA Method 6010B. 2000. "Inductively Coupled Plasma-Atomic Emission Spectrometry.” Test Methods for Evaluating Solid Waste, Physical/Chemical Methods. EPA Publication SW-846, available online http://www.epa.gov/epaoswer/hazwaste/test/sw846.htm

EPA Method 6020. 2000. "Inductively Coupled Plasma-Mass Spectrometry.” Test Methods for Evaluating Solid Waste, Physical/Chemical Methods. EPA Publication SW-846, available online http://www.epa.gov/epaoswer/hazwaste/test/sw846.htm

EPA Method 300.1, Rev. 1. 2000. "Determination of Inorganic Anions in Drinking Water by Ion Chromatography." Methods for the Determination of Organic and Inorganic Compounds in Drinking Water, Volume 1, EPA 815-R-00-014, U. S. Environmental Protection Agency, National Exposure Research Laboratory, Cincinnati, Ohio.

Lindberg JW and FW Bond. 1979. Geohydrology and Ground-Water Quality Beneath the 300 Area, Hanford Site, Washington. PNL-2949, Pacific Northwest Laboratory, Richland, Washington.

Peterson RE, EJ Freeman, PD Thorne, MD Williams, JW Lindberg, CJ Murray, MJ Truex, SB Yabusaki, JP McDonald, VR Vermeul, and JM Zachara. 2005. Contaminants of Potential Concern in the 300-FF-5 Operable Unit: Expanded Annual Groundwater Report for Fiscal Year 2004. PNNL-15127, Pacific Northwest National Laboratory, Richland, Washington.

PNNL. 1994, as revised. Procedures for Ground-Water Investigations. PNL-MA-567, Pacific Northwest National Laboratory, Richland, Washington.

PNNL. 1998, as revised. Inductively Coupled Plasma Mass Spectrometric (ICP-MS) Analysis. PNNLAGG-415, Pacific Northwest National Laboratory, Richland, Washington.

PNNL. 2000, as revised. Inductively Coupled Plasma-Optical Emission Spectrometry (ICP-OES) Analysis. PNNL-AGG-ICP-AES, Pacific Northwest National Laboratory, Richland, Washington.

PNNL. 2004, as revised. Determinations by Ion Chromatography (IC). PNNL-AGG-IC-001, Pacific Northwest National Laboratory, Richland, Washington.

Serne RJ, CF Brown, HT Schaef, EM Pierce, JW Lindberg, Z Wang, PL Gassman, and JG Catalano. 2002. The 300 Area Uranium Leach and Adsorption Project. PNNL-14022, Pacific Northwest National Laboratory, Richland, Washington.

Schalla R, RW Wallace, RL Aaberg, SP Airhart, DJ Bates, JVM Carlile, CS Cline, DI Dennison, MD Freshley, PR Heller, EJ Jensen, KB Olsen, RG Parkhurst, JT Rieger, and EJ Westergard. 1988. Interim Characterization Report for the 300 Areas Process Trenches. PNL-6716, Pacific Northwest Laboratory, Richland, Washington. 
WAC 173-160. “Minimum Standards for Construction and Maintenance of Wells.” Washington Administrative Code, Olympia, Washington.

Waichler SR and SB Yabusaki. 2005. Flow and Transport in the Hanford 300 Area Vadose ZoneAquifer-River System. PNNL-15125, Pacific Northwest National Laboratory, Richland, Washington.

Wellman DM, JP Icenhower, and AT Owen. 2006. “Comparative Analysis of Soluble Phosphate Amendments for the Remediation of Heavy Metal Contaminants: Effect on Sediment Hydraulic Conductivity.” Environmental Chemistry, 3, 219-224.

Zachara JM (ed.) JA Davis, C Liu, JP McKinley, N Qafoku, DM Wellman, and SB Yabusaki. 2005. Uranium Geochemistry in Vadose Zone and Aquifer Sediments from the 300 Area Uranium Plume. PNNL-15121, Pacific Northwest National Laboratory, Richland, Washington. 


\section{Distribution*}

No. of

Copies

\section{DOE-Richland Operations Office}

K. M. Thompson

Public Reading Room (2)
No. of

Copies

8 Pacific Northwest National Laboratory

$\begin{array}{lr}\text { J. S. Fructher } & \text { K6-96 } \\ \text { R. E. Peterson } & \text { K6-75 } \\ \text { V. R. Vermeul } & \text { K6-96 } \\ \text { D. M Wellman } & \text { K3-62 } \\ \text { B. A. Williams } & \text { K6-75 } \\ \text { M. D. Williams } & \text { K6-96 } \\ \text { Hanford Technical Library(2) } & \text { P8-55 }\end{array}$

*This document is being distributed electronically.

Distr. 1 